\title{
Characteristics of Indigenous Chicken of the North Central Agro-ecological Zone of Nigeria
}

\author{
Okoh Joseph Joseph ${ }^{1}$, Haruna Alkali ${ }^{1}$, Yakubu Ibrahim ${ }^{1}$, Ma'aruf Bashir Sani ${ }^{1}$, Bala Dafur ${ }^{2}$, \\ Odiba Abdulkadir Arome ${ }^{3}$, Torhemen Michael ${ }^{4}$ \\ ${ }^{1}$ Department of Animal Science, Federal University of Kashere, Gombe, Nigeria \\ ${ }^{2}$ Department of Animal Production, University of Jos, Nigeria \\ ${ }^{3}$ Department of Animal Science, Ahmadu Bello University, Zaria, Nigeria \\ ${ }^{4}$ Department of Animal Husbandry, Akperan Orshi College of Agriculture, Yandev-Gboko, Nigeria
}

\section{Email address:}

\section{To cite this article:}

Okoh Joseph Joseph, Haruna Alkali, Yakubu Ibrahim, Ma'aruf Bashir Sani, Bala Dafur, Odiba Abdulkadir Arome, Torhemen Michael. Characteristics of Indigenous Chicken of the North Central Agro-ecological Zone of Nigeria. Animal and Veterinary Sciences. Special Issue: Promoting Animal and Veterinary Science Research. Vol. 8, No. 3, 2020, pp. 60-64. doi: 10.11648/j.avs.20200803.13

Received: December 17, 2019; Accepted: February 24, 2020; Published: June 28, 2020

\begin{abstract}
The study assessed the productive performance of adult indigenous chicken from four Nigerian states of the North Central Zone namely; Nasarawa, Niger, Benue, Kogi and the Federal Capital Territory (FCT). Data were collected at both Out and On-station. The result showed that flock structure was in proportion of 28, 21.4, 23.2 and 27.5\% for cock, hen, growers and chicks. Chi-square showed significant difference $(\mathrm{P}<0.001)$ by state. Clutch size ranged from $10.84 \pm 0.23$ to $11.45 \pm 0.23$ in FCT and Nasarawa state. On-station clutchsize was $13.11 \pm 0.23$. There was significant difference $(\mathrm{P}<0.001)$ by site while state has similar values. Age at first egg, clutch number and hatchability did not vary significantly. However, there was significant difference $(\mathrm{P}<0.05)$ in Chick mortality which ranged from 43.19 to $53.89 \%$ in Benue and the FCT. On-stationmortality was $26.78 \%$. Correlation coefficient between egg and production traits showed that most correlation traits were significant at $1 \%$. Only number of chicks hatched, egg wasted, egg width and length and mortality were correlated at 5\%. Some common diseases showed that Newcastle is the most prevalent $63.22 \%$. Farmers attached a high preference to keeping male chicken for sale rather than breeding purposes. The high hatchability is an indication of good reproductive performance in the chickens of the study area. Improvement in management practices and vaccination against Newcastle disease should be adopted to curtail its devastating effect on indigenous chicken production in the study area.
\end{abstract}

Keywords: Clutch, Hatchability, Indigenous Chicken, Mortality, Body Weight, Disease

\section{Introduction}

Productivity is a function of the animals' genetics, anatomy, physiology, nutrition, age, management and the environment [1]. One of the parameter for measuring production in poultry is egg production. Egg production is mostly measured as number of eggs per clutch or hen housed or hen-day production. It is the number of eggs from the clutches per bird per year [2]. Age at first egg production is variable because it is affected by feeding and management practice [1]. Age influences egg production within the first and subsequent laying cycles.

The potential for egg production in indigenous chickens is about 30 to 40 eggs per annum [3]. Average annual egg production of indigenous chickens under the village conditions was reported to be 30- 60 eggs [4]. Chickens, however, lay eggs on successive days collectively called the clutch with intermediate pauses of one or more days. The total number of eggs in a clutch is the clutch size [5]. Numbers of clutch sizes per year are used to measure egg production under scavenging condition. Under intensive management system, $16 \pm 1.0$ clutches with an average size of $3.1 \pm 0.2$ eggs for the Nigerian indigenous chicken in a short term egg production period (Point of lay - 120 days of lay) has been reported [5]. Under extensive system, they lay up to three clutches of $12-18$ eggs per year [6]. Average 
clutches / year and clutch size of 2.9 and 10.4 respectively for Nigerian indigenous chicken under scavenging system has also been reported [7]

Hatchability refers to set egg that hatch [8] which is depended on both egg weight and ratio of weight to shell surface area. Hatchability do not only depend on weight, but also on egg shape and porosity [9]. This study assessed the productive performance of indigenous chicken for production indexes of clutch, age at first egg, hatchability, flock structure, chick mortality and diseases.

\section{Materials and Methods}

\subsection{Study Location}

The study was carried out in the North Central Zone of Nigeria which has an average elevation of 1,300 $\mathrm{m}$ above sea level. The longitudes and latitudes of the areas are; Benue $\left(7^{\circ}, 12^{\prime} \mathrm{N} ; 7^{\circ}, 29^{\prime} \mathrm{N}\right.$ and $\left.8^{\circ}, 45^{\prime} \mathrm{E} ; 9^{\circ}, 24^{\prime} \mathrm{E}\right), \operatorname{Kogi}\left(7^{\circ}, 12^{\prime} \mathrm{N} ; 7^{\circ}\right.$, $56^{\prime} \mathrm{N}$ and $\left.7^{\circ}, 11^{\prime} \mathrm{E} ; 6^{\circ}, 58^{\prime} \mathrm{E}\right)$, Nasarawa $\left(8^{\circ}, 35^{\prime} \mathrm{N} ; 8^{\circ}, 37^{\prime} \mathrm{N}\right.$ and $\left.8^{\circ}, 09^{\prime} \mathrm{E} ; 9^{\circ}, 02^{\prime} \mathrm{E}\right)$, Niger $\left(9^{\circ}, 27^{\prime} \mathrm{N} ; 9^{\circ}, 46^{\prime} \mathrm{N}\right.$ and $6^{\circ}$, $\left.31^{\prime} \mathrm{E} ; 7^{\circ}, 01^{\prime} \mathrm{E}\right)$ and the Federal Capital Territory (FCT) $\left(9^{\circ}\right.$, $09^{\prime} \mathrm{N} ; 9^{\circ}, 20 ' \mathrm{~N}$ and $\left.7^{\circ}, 14^{\prime} \mathrm{E} ; 6^{\circ}, 4^{\prime} \mathrm{E}\right)[10]$

\subsection{Climate and Vegetation}

The North Central Agro - ecological zone of Nigeria experiences a sub humid tropical climate with two distinct seasons, rainy and dry. The rainy season lasts from April to September and received from $1000-2500 \mathrm{~mm}$ of rain, while the dry begins in October and ends in March. The two seasons are due to the moisture laden south westerly-wind from the Atlantic Ocean and the dry dusty north-easterly from the Sahara Desert [11]. Temperatures are high throughout the year averaging $30^{\circ} \mathrm{C}$. Mean annual temperatures per state are Benue $30^{\circ} \mathrm{C}$, Nasarawa $31^{\circ} \mathrm{C}$, Kogi $29^{\circ} \mathrm{C}$, Niger $30^{\circ} \mathrm{C}$ and the Federal Capital Territory $29^{\circ} \mathrm{C}$. The relative humidity ranged from 47 to $85 \%$ [12]. The study area experienced mean daily sunshine duration of 8 hours [13]. The vegetation varies considerably. It is best described as savanna, a region of tall grasses and trees.

\subsection{Occupation}

Farming is the main occupation in the area. Crops cultivated includes: Yam, Soya beans, Rice, Cowpea, Cassava, Sweet potatoes, Sorghum, Maize, Millet, Cocoyam etc. Livestock and poultry are mainly kept as part time farming activities; Cattle, sheep, goats, chickens, ducks, geese, turkeys, pigeons and guinea fowls are kept.

Birds used for the study were scavenging indigenous chickens found within the study area and data were collected as Out - and - On stations

\subsection{Management}

Traditional management was practiced in the study area. Marked areas were provided for birds at night but are allowed to scavenge freely in the day. Supplementary feeds in the form of house- hold refuse and grains were usually given in the morning before scavenging and later in the evening before rest. Water was supplied at various locations around the home. No vaccination was given and, diseases were controlled by slaughtering affected chickens.

\subsection{Traits Measured}

Data on productivity parameters were obtained as follows:

Age at first egg - the number of days from hatch to the day the first egg waslaid provided a second egg was laid in the next ten days.

Clutch size- the total number of eggs laid by indigenous chicken per clutch

Hatchability- the total number of eggs hatched to the total number incubated

$$
\text { (Eh / Ei) x } 100
$$

Where:

$\mathrm{Eh}=$ Total number of eggs hatched

$\mathrm{Ei}=$ Total number of eggs incubated.

Clutch Number- the number of laying cycle per year.

Mortality (chick) - the total number of hatched or weaned chicks that died.

Common poultry diseases were assessed to determine their prevalence

\subsection{Statistical Analysis}

Qualitative data were classified into different categories, percentages calculated and chi-squares $\left(\chi^{2}\right)$ were used to test the significance of proportion.

Where:

$$
\chi^{2}=(\mathrm{O}-\mathrm{E})^{2} / \mathrm{E}
$$

$\mathrm{O}=$ Observed values

$\mathrm{E}=$ Expected values

Pearson's Correlation co- efficient was computed to test the relationship within and between productivity parameters.

\section{Results and Discussion}

\subsection{Flock Structure}

Flock structure (Table 1) revealed overall proportion of 28 , 21.4, 23.2 and $27.5 \%$ for cock, hen, growers and chicks, respectively. Chi-square showed significant difference ( $\mathrm{P}$ $<0.001$ ) between states. Cock population was highest 38.13, 33.99 , and $30.25 \%$ in Benue, Kogi and Nasarawa. However, chick and grower populations were highest in Niger and Abuja with values of 29.16 and $28.84 \%$, respectively. Chisquares tests revealed significant $(\mathrm{P}<0.001)$ percentage variation within states. The variation in sex percentage in favour of cock may have arisen due to the preference attached to keeping males for economic (sale) rather than breeding purposes [14]. This observation does not agree with reports from other parts of Africa where sex percentage favoured hens. In Ethiopia the proportion was 3.49 hens, 1.31 
cocks, 3.18 growers, 3.92 chicks while Gambia had 2.22 hens, 0.68 cocks [15]. Meat and tradition had been found to be the most frequent motivation for farmers in keeping high number of male indigenous chickens. The flock structure reported in this study can be used to predict flock dynamics [16] of mature hens for the estimation ofchicken productivity and chick survival which are the key parameters used to study village chicken flock characteristics [15].

Table 1. Flock structure (\%) by state.

\begin{tabular}{|c|c|c|c|c|c|c|c|c|c|}
\hline Variable & Benue & Kogi & Nasarawa & Niger & Abuja & Total & $\chi^{2}$ & LS & df4 \\
\hline Cock & 38.13 & 33.99 & 30.25 & 21.58 & 21.03 & 28.0 & 678.394 & $* * *$ & \\
\hline Hen & 22.74 & 19.70 & 16.79 & 23.34 & 23.84 & 21.3 & 153.003 & $* * *$ & \\
\hline Growers & 18.73 & 16.47 & 22.77 & 25.92 & 28.84 & 23.2 & 370.643 & $* * *$ & \\
\hline Chicks & 20.40 & 29.64 & 30.25 & 29.16 & 26.29 & 27.5 & 180.018 & $* * *$ & \\
\hline Total & 15.6 & 17.0 & 21.2 & 23.1 & 23.2 & 100 & 1382.058 & $* * *$ & \\
\hline$\chi^{2}$ & $436.843 * * *$ & $262.244 * * *$ & $132.927 * * *$ & $206.278 * * *$ & $343.766^{* * *}$ & & & & \\
\hline
\end{tabular}

$\mathrm{df}=3 * * *=$ significant at $\mathrm{P}<0.001$. Figures are percentages

\subsection{Common Disease}

Newcastle disease (Table 2) was the most prevalent $63.22 \%$; this was also true for all the states studied. Prevalent rate in Newcastle vary between $59.2 \%$ to $73.20 \%$ in Abuja and Benue, respectively. The highest incidence of Coccidiosis $32.0 \%$ was in Niger and the least $20.20 \%$ in Kogi state. Incidences of Chronic respiratory diseases were low in all states, with $10.3 \%$ in the entire population. Fowl pox $(2.5 \%)$ and Fowl cholera $(0.87 \%)$, were even lower. Chi- squares tests revealed significant $(\mathrm{P}<0.001)$ percentage variation within states. Poor sanitary practices might have been the reason for the frequent predisposition of indigenous chickens to common poultry diseases such as Newcastle disease and Coccidiosis. Free movement of large populations of indigenous chickens, ducks and free flying birds predisposes the indigenous chicken to diseases [17]. Newcastle disease ranked among the most important disease of poultry in Nigeria.

Table 2. Disease prevalence.

\begin{tabular}{|c|c|c|c|c|c|c|c|c|c|}
\hline \multicolumn{10}{|l|}{$\%$ Incidence per State } \\
\hline Diseases & Benue & Kogi & Nasarawa & Niger & Abuja & Total & $\chi^{2}$ & $\mathbf{L S}$ & df4 \\
\hline Newcastle & $366(73.20)$ & $312(62.4)$ & $301(60.20)$ & $296(59.20)$ & $312(62.40)$ & $1587(63.22)$ & 81.22 & $* * *$ & \\
\hline Coccidiosis & $102(20.40)$ & $101(20.20)$ & $102(20.40)$ & $160(32.00)$ & $114(22.80)$ & $579(23.06)$ & 16.71 & $* * *$ & \\
\hline Chronic Respiratory Disease & $20(4.00)$ & $66(13.20)$ & $70(14.00)$ & $51(10.20)$ & $52(10.40)$ & $259(10.32)$ & 31.32 & $* * *$ & \\
\hline Fowl Pox & $10(2.00)$ & $18(3.60)$ & $14(2.80)$ & $02(0.40)$ & $19(3.80)$ & $63(2.51)$ & 26.75 & $* * *$ & \\
\hline Fowl Cholera & $02(0.40)$ & $03(0.60)$ & $13(2.60)$ & $01(0.20)$ & $03(0.60)$ & $22(0.87)$ & 28.97 & $* * *$ & \\
\hline
\end{tabular}

Note: Figures in parenthesis are percentages

\subsection{Productivity}

Clutch size (Table 3) ranged from $10.84 \pm 0.23$ to $11.45 \pm$ 0.23 in Abuja and Nasarawa, respectively. On- station clutch size was $13.11 \pm 0.23$. There was significant difference $(\mathrm{P}<0.001)$ in clutch size by site while states had similar values. Number of eggs incubated ranged from $8.71 \pm 0.01$ to $11.38 \pm 0.32$ in Benue and Nasarawa state, which was significant $(\mathrm{P}<0.001)$ by location. Age at first egg, clutch number and hatchability did not vary significantly. However, there was significant difference $(\mathrm{P}<0.05)$ in chick mortality which ranged from 43.19 to $53.89 \%$ in Benue and Abuja. Onstation mortality value stood at $26.78 \%$. Work from three agroecological zones of derived, guinea savannah and, rainforest of Nigeria reported AFE to be $157 \pm 3.7,160 \pm 3.8$ and $165 \pm 3.7$ days [18]. However, AFE reported in this study $149 \pm 2.71$ was less than those reported for other ecological zone but similar to that of indigenous chicken ecotype of Ethiopia 144 days [19] and 144.3 days for indigenous chicken ecotypes of Tanzania [20]. There were fairly good clutch size and hatchability in the present study. Clutches / year of $16 \pm 1.0$ has been reported [5]. Average clutch size of 10.4 for Nigerian indigenous chicken under scavenging system has been reported [21]. Hatchability in this study is higher than $62 \%$ reported earlier [22]. Values of $75 \%$ [7], 90\% [23] and, 88.70 $\pm 1.48,82.55 \pm 1.23,84.25 \pm 1.04$ and $83.87 \pm 1.26 \%$ for frizzle, dwarf, naked neck and normal feathered chickens have also been reported [24]. The good hatchability recorded might be due to moderate egg weight and shell qualities since hatchability is influenced by these factors. With high egg weight, hatchability is reduced, but it increased with moderate values which in turn affect post hatch mortality [10]. The high percentage hatchability recorded in this study is an indication of good reproductive performance.

Table 3. Productivity of indigenous chickens.

\begin{tabular}{|c|c|c|c|c|c|c|c|c|}
\hline Variable & Benue & Kogi & Nasarawa & Niger & Abuja & Average & On station & $\mathbf{L S}$ \\
\hline $\mathrm{AFE}$ & $150 \pm 2.23$ & $146 \pm 2.80$ & $151 \pm 3.00$ & $156 \pm 3.03$ & $143 \pm 2.52$ & $149 \pm 2.71$ & $141 \pm 2.23$ & NS \\
\hline $\mathrm{CN}$ & $3.31 \pm 0.03$ & $3.06 \pm 0.43$ & $3.03 \pm 0.11$ & $3.23 \pm 0.23$ & $3.00 \pm 0.53$ & $3.13 \pm 0.26$ & $3.22 \pm 0.13$ & NS \\
\hline $\mathrm{CS}$ & $11.20 \pm 0.12^{\mathrm{b}}$ & $11.24 \pm 0.11^{\mathrm{b}}$ & $11.45 \pm 0.23^{\mathrm{b}}$ & $10.95 \pm 0.15^{\mathrm{b}}$ & $10.84 \pm 0.23^{\mathrm{b}}$ & $11.14 \pm 0.17$ & $13.11 \pm 0.23^{\mathrm{a}}$ & ${ }^{* * *}$ \\
\hline N EI & $8.71 \pm 0.01^{\mathrm{c}}$ & $11.17 \pm 0.21^{b}$ & $11.38 \pm 0.32^{b}$ & $10.70 \pm 0.06^{b}$ & $10.32 \pm 0.15^{b}$ & $10.48 \pm 0.14$ & $11.01 \pm 0.23^{\mathrm{a}}$ & ${ }^{* * *}$ \\
\hline NEh & $8.48 \pm 0.42^{c}$ & $10.93 \pm 0.63^{b}$ & $11.28 \pm 0.44^{b}$ & $10.43 \pm 0.03^{b}$ & $10.14 \pm 0.06^{b}$ & $10.25 \pm 0.02$ & $13.11 \pm 0.16$ & $* * *$ \\
\hline
\end{tabular}




\begin{tabular}{|c|c|c|c|c|c|c|c|c|}
\hline Variable & Benue & Kogi & Nasarawa & Niger & Abuja & Average & On station & $\mathbf{L S}$ \\
\hline NCW & $3.91 \pm 0.63^{c}$ & $5.29 \pm 0.72^{b}$ & $5.21 \pm 0.07^{b}$ & $5.20 \pm 0.41^{b}$ & $5.76 \pm 0.06^{b}$ & $5.04 \pm 0.06$ & $9.60 \pm 0.44^{\mathrm{a}}$ & $* * *$ \\
\hline $\mathrm{HB}$ & $97.36 \pm 0.33$ & $97.85 \pm 0.41$ & $99.12 \pm 0.26$ & $97.48 \pm 0.43$ & $98.26 \pm 0.32$ & $98.01 \pm 0.35$ & $94.81 \pm 0.45$ & NS \\
\hline MT & $\begin{array}{l}4.57 \pm 0.32^{b} \\
(53.89)\end{array}$ & $\begin{array}{l}5.64 \pm 0.02^{b} \\
(51.60)\end{array}$ & $\begin{array}{l}6.07 \pm 0.04^{b} \\
(53.81)\end{array}$ & $\begin{array}{l}5.23 \pm 0.35^{b} \\
(50.14)\end{array}$ & $\begin{array}{l}4.38 \pm 0.32^{b} \\
(43.19)\end{array}$ & $\begin{array}{l}5.18 \pm 0.32 \\
(41.89)\end{array}$ & $\begin{array}{l}3.51 \pm 0.01^{a} \\
(26.78)\end{array}$ & $* *$ \\
\hline
\end{tabular}

Note: $* *=(\mathrm{P}<0.01) . * *=(\mathrm{P}<0.001)$. Means in row with different superscripts are significantly different. Figures in parenthesis are percentage. AFE $=$ Age at first egg, $\mathrm{CN}=$ Clutch number, $\mathrm{CS}=$ Clutch Size, $\mathrm{NEI}=$ Number of eggs incubated, $\mathrm{NCW}=$ No of chicks weaned, $\mathrm{HB}=\mathrm{Hatchability,} \mathrm{MT}=\mathrm{Mortality}$.

\subsection{Relationship Between Egg Characteristics and Production Traits}

Correlation coefficients between egg production traits of indigenous chickens (Table 4) showed that most correlation values were significant at $1 \%$. Only number of chicks hatched to number of egg wasted, egg width, egg length and mortality were correlated at 5\%. Most egg production traits are lowly correlated. The positive correlation of mature hen weight with egg production characteristics is an indication of possible genetic responses in the former by selection for the latter. Improvement could be feasible by selecting for characteristics which can be assessed easily.

Table 4. Correlation among performance traits in the study area.

\begin{tabular}{|c|c|c|c|c|c|c|c|c|c|c|c|}
\hline & MHW & CS & No. El & No.Ch & No. EW & NO. CW & Hby & Av. Ewt & AV. El & Av. Ewi & Av.Mt \\
\hline MHW & & $0.146 * *$ & $0.071 \mathrm{~ns}$ & $0.024 \mathrm{~ns}$ & 0.066 & $0.014 \mathrm{~ns}$ & $0.168 * *$ & $0.162 * *$ & $0.123 * *$ & $0.162 * *$ & 0.048 \\
\hline $\mathrm{CS}$ & & & $0.174 * *$ & $0.104 \mathrm{~ns}$ & $-0.006 \mathrm{~ns}$ & $0.018 \mathrm{~ns}$ & -0.018 & -0.031 & -0.089 & -0.054 & $-0.014 \mathrm{~ns}$ \\
\hline No. El & & & & $-0.014 n s$ & $0.170 * *$ & -0.053 & -0.008 & -0.096 & $0.008 \mathrm{~ns}$ & 0.012 & $0.097 *$ \\
\hline No.Ch & & & & & $0.054 *$ & $0.008 \mathrm{~ns}$ & $0.013 \mathrm{~ns}$ & $-0.012 \mathrm{~ns}$ & $0.017 \mathrm{~ns}$ & $0.057 *$ & $0.009 \mathrm{~ns}$ \\
\hline No. EW & & & & & & $0.017 \mathrm{~ns}$ & 0.047 & $0.009 \mathrm{~ns}$ & $0.017 \mathrm{~ns}$ & 0.047 & $0.009 \mathrm{~ns}$ \\
\hline NO. CW & & & & & & & -0.036 & $0.122 * *$ & $0.017 \mathrm{~ns}$ & 0.047 & $0.009 \mathrm{~ns}$ \\
\hline Hby & & & & & & & & $0.189 * *$ & $0.033 \mathrm{~ns}$ & $0.054 \mathrm{~ns}$ & $0.032 \mathrm{~ns}$ \\
\hline AV. El & & & & & & & & & & $0.064 \mathrm{~ns}$ & $0.087 \mathrm{~ns}$ \\
\hline Av. Ewi & & & & & & & & & & & $0.033 \mathrm{~ns}$ \\
\hline Av.Mt & & & & & & & & & & & \\
\hline
\end{tabular}

$*=$ Significant at $\mathrm{P}<0.05 * *=$ Significant at $\mathrm{P}<0.01 . \mathrm{AV}=$ Average, $\mathrm{Wt}=$ weight, $\mathrm{El}$, =eggs incubated,

$\mathrm{CH}=$ chick hatched, $\mathrm{W}=$ eggs wasted, $\mathrm{CW},=$ chicks weaned $\mathrm{Hb}=$ hatchability, Ewt $=$ egg weight,

$\mathrm{EL}=$ egg length, Ewi=egg width.

\section{Conclusion}

Conclusively, the generally high percentage of males in the flock indicated that productivity was more commercial than general breeding. Newcastle disease is the major challenge to chicken production in the study area. The high egg hatchability is an indication of good reproductive performance in the chickens.

\section{Recommendations}

Sanitation and health care should be strictly adhered to, in order to prevent most of the common diseases. Efforts should be made to vaccinate indigenous chicken against common fowl diseases such as Newcastle diseases and Coccidiosis, which are highly endemic in the study area. To adequately meet the shortfall of protein requirement and income of rural dwellers; there should be deliberate and sustainable improvement programmes for indigenous chickens for egg especially using correlated traits.

\section{References}

[1] K. John (2018). Important factor affecting poultry egg production in poultry. agrihomeph.com https://blog.agrihomegh.com/poultry-egg-production
[2] Y. P. Mancha (2004). Characterization of Indigenous Chickens in Northern Part of the Jos Plateau. A Ph.D Thesis Animal Production Programme, School of Agriculture, Abubakar Tafawa Balewa University. Bauchi.

[3] D. Tadelle, and B. Ogle (2001). Village poultry production systems in the central highlands of Ethiopia. Tropical Animal Health Production, 33 (6), 521-537.

[4] E. Brannangand S. Pearson (1990). Ethiopian Animal Husbandry, Uppsala, Sweden, P 127.

[5] S. S. I. Omeje,. and C. C. Nwosu, (1984). Heterosis and superiority in body weight and feed efficiency evaluation of exotic parent stock by indigenous chicken $\mathrm{F}_{1}$ crosses. Nigerian Journal of Genetics, 1: 11-26.

[6] G. Williamson and W. J. A. Payne (1978). An Introduction to Animal Husbandryin the Tropics, $4^{\text {th }}$ Ed. LLB and Longman Group Limited, London.

[7] E. O., Otchere, A. T. Adeoye, J. O. Gefu, and A. A. Adenuyi, (1990). Preliminary observations on village chicken production in north-central Nigeria. In: Rural Poultry Production in Africa. Editor. Sonaiya, E. B. Proceedings of an International Workshop on Rural Poultry in Africa. Ile-Ife, Nigeria, 13-16 November, 1989. Pp 196-200.

[8] F. O. Ajayi, and B. O. Agaviebor, (2006). Fertility and hatchability performance of pure and crossbred indigenous chicken strains in the high rainforest zone of Nigeria. International Journal of Livestock production, 7 (12) 141-144.

[9] D. C. Deeming (1995). Large eggs: an incubation challenge. Poultry International. 35 (14): 50-54. 
[10] Microsoft Encarta, (2008). Geography Search.

[11] BSN (Benue State of Nigeria), (1982). The Government and People of Benue State. Benue State Gazette. Benue State Ministry of Information. Onaiviprestery press. Pp 1-9.

[12] A. A., Amusan, A. Olayinka, and D. J. Oyedele, (2003). Characterization, classification and evaluation of soil Aeolian sand in the guinea savannah of Nigeria. Proceeding of the $47^{\text {th }}$ Conference of Agricultural society of Nigeria. $24^{\text {th }}$ to 28 October, 2003. Pp $374-378$.

[13] TAC (2002). Technical Air Command Makurdi. Meterological Station. Makurdi Weather Elements records.

[14] S. T. Mbap and H. Zakar,. (2000). Characterization of local chickens in Yobe State, Nigeria In: The Role of Agriculture in Poverty Alleviation. Abubakar, M. M., Adegbola, T. A. and Butswat, I. S. R. (Editors) Proceeding of the $34^{\text {th }}$ Annual Conference of the Agricultural Society of Nigeria (ASN) October 15-19, 2000, Bauchi, Pp 126-131.

[15] J. K. Aichi (1995). Village chicken production systems in rural Africa: Household food security and gender issues; Food and Agricultural Organization. Animal Production and Health paper, 142: 25-57.

[16] I. Abdouand J. G. Bell (1992). Dynamique de la volaillevillageoisedans la region de kaita au Niger. In Village Poultry Production in Africa. Proceedings of an International Workshop Held in Rabat Morocco, 7 - 11. Pp. 6-11.

[17] D. R. Nawathe, and A. G. Lamorde, (1987). Newcastle disease and poultry farming in Nigeria. Journal of National Veterinary Research Institute, 7 (1-4). 7-10.

[18] S. A. Adedokun, and E. B. Sonaiya, (2001). Comparison of the performance of Nigerian indigenous chickens from three agroecological zones. Livestock Research forRural Development, 3 (2): 34-39.

[19] H. H. Mogesse, (2007). Phenotypic and genetic characterization of indigenous chicken population in Northwest Ethiopia. Ph.D. Thesis. Department of Animal, Wildlife and Grassland Science. University of the Free-state, Bloemfontein, South Africa.

[20] M. Ali, M. Farooq, F. R. Durrani, N. Chand, K. Sarbiland, and A. Riaz, (2003). Egg production performance and prediction of standard limits for traits of economic importance inbroiler breeders. Journal of Poultry Science, 2 (4) 275-279.

[21] A. Barua, and Y. Yoshimura (1997). Rural poultry keeping in Bangladesh. World Poultry Science Journal, 53: 387- 394.

[22] P. L. M Msoffe, M. M. A. Mtambo, U. M. Minga, J. E. Olsen, H. R., Juul-Madesen, P. S Gwakisa,, et al. (2004). Productivity and reproductive performance of the free-range indigenous domestic fowl ecotypes in Tanzania. Livestock Research and Rural Development, 16 (9), 160-167. http://www.cipav.org.co/lrrd/lrrd16/9/msof16067.htm

[23] R. T. Wilson, (1979). Studies on the livestock of southern Darfur, Sudan. Production of poultry under simulated traditional conditions. Tropical Animal Health Production. 11: 143-150.

[24] J. J. Okoh, A. I. Adeka, E. E Idogah, and M. I. Aku, (2010). The Effects of major gene on feather traits of local chickens in Benue State of Nigeria. In: Fast Tracking Animal Agriculture In A Challenging Economy. O. J. Babayemi; O. A. Abu; E. O. Ayeola (Editors). Proceeding of the Nigeria Society for Animal Production $35^{\text {th }}$ Annual Conference, Ibadan, 2010, Pp 95-98. 